\title{
The Non-essential Elements of Satire
}

\subsection{Introduction}

I have demonstrated that the $\mathrm{SN}$ has a pervasive sense of irony and, indeed, of verbal irony. My application of Muecke's taxonomy of verbal irony to the SN revealed numerous important examples of verbal irony. This finding in itself is probably sufficient to demonstrate that the $\mathrm{SN}$ is a work of satire. However, to demonstrate with certainty that the $\mathrm{SN}$ is a work of satire it is necessary also to provide evidence of at least some of the other features of satire (i.e. other than verbal irony and an object of satirical attack). For the description of these additional features I rely on Marcus. Marcus' additional features of satire are as follows: fantastic events; grotesqueries; distortions; ridicule; parody; and/ or rhetorical features. The SN has been mined for the presence of examples of these additional features of satire. These examples are listed below. Of note, some of the examples which have been listed could fit into more than one category. For instance, in 2 Samuel 12:30 David puts onto his head a crown which weighs the same as a person. This could be interpreted as a fantastic event since this is an impossible thing to do, or as a distortion since this is an exaggeration.

An issue arises with respect to one of these additional features of satire, namely, parody. Marcus has a description of parody. However, Muecke also has a description of parody. Their descriptions for the most converge. For example, both Marcus and Muecke hold that parody is primarily the distortion of a known text, expression or custom. However, Marcus' description of parody ${ }^{1}$ differs in some respects from Muecke's. Marcus' description of parody includes puns, paronomasia, exaggeration and general mocking. By contrast, Muecke locates the latter phenomena outside his description of parody in stand-alone sub-categories of impersonal irony (at least in most cases.) The consequence of this for us is that one and the same example will be classified as parody by the light of Marcus' taxonomy but not necessarily by the lights of Muecke's. Therefore, the classification of some of the episodes mentioned below may involve a double description (one being Marcus', the other Muecke's). However, this classicatory anomaly does not signal substantive disagreement in respect of the episode classified. In any case, there are very few such cases. I emphasise

1 Marcus, From Balaam to Jonah. Anti-prophetic Satire in the Hebrew Bible, 18. 
that all that is required from this section-in the context of my demonstration that the $\mathrm{SN}$ is a satire-is that there are elements of some of these features in the SN. For it is the pervasive sense of verbal irony that carries the burden of the argument that the $\mathrm{SN}$ is satire. Moreover, even if some of the more contentious examples are removed there would remain an overwhelming number of examples evidencing satire.

\subsubsection{Fantastic Events in the Succession Narrative}

Marcus writes that fantastic events are those events which are either impossible or highly improbable. ${ }^{2}$

12:30 - David puts the crown which is the weight of a human being on his head. 14:26 - the annual clippings of Absalom's hair are said to weigh four and a half pounds, which is inconceivable. The presence of God might be considered a fantastic event. 18:9 — it might be considered to be a fantastic event that Absalom was hung in a tree by his head. In 19:18 it is claimed that Ziba split the Jordan and damned it up again in order to meet David.

\subsubsection{Grotesqueries}

Grostesqueries are defined by Marcus as actions which are characterised by violence, violations, or obscenities. Examples of grotesqueries are as follows, “... beatings, mutilations, killings, murder, rape, incest, and cannibalism, and vulgarities such as obscenity, and scatology.'

11:4-it may be assumed that adultery is a grotesquery, as it is contrary to a stringent moral norm, and the punishment for this act is the death penalty. 11:5—if David defiles himself by sleeping with Bathsheba when she is in a state of ritual impurity, then this is a grotesquery. 11:8-David suggests that Uriah defile himself by sleeping with Bathsheba when Israel is at war. 11:14-15David writes a note that Uriah is to be killed in fighting; David is attempting to cover-up his own transgression. 11:16-17-Uriah is killed, as are other innocent soldiers. 11:25-David's message to Joab that men die in war all the time is grotesque. 13:11-Amnon restrains Tamar. 13:14 Amnon rapes Tamar. 13:15-16after raping Tamar, Amnon throws her out of the house, knowing that her life is ruined. 13:29—Amnon is executed on Absalom's command. 14:30—Absalom's decision to burn Joab's farm, might be considered a grotesquery since it is a violent act. The war itself is, of course, violent and, therefore, a grotesquery. I Kgs. 20:10-Joab kills Amasa. I Kgs. 2:5-6-David says that Joab should not

2 Marcus, From Balaam to Jonah. Anti-Prophetic Satire in the Hebrew Bible, 10.

3 Ibid., 11-12. 
go down to Sheol in peace. I Kgs. 2:7-David tells Solomon to send Shimei down to Sheol in blood. I Kgs. 2:25 — Benaiah kills Adonijah. I Kgs. 2:34-35Benaiah kills Joab, who is undeserving of death, at the holiest place in Israel.

\subsubsection{Distortions}

Marcus speaks of distortions as largely being exaggerations or understatements. ${ }^{4}$

9:1-10-David's mention of חסד is exaggerated. 9:10-13-9:10-13a is overstated and the information in 9:13b is curt. 11:1-there is an exaggeration in the verbosity in verse 11:1a and an understatement in 11:1b. 11:2-11:2a is prolix, and 11:2b is curt (when David spies Bathsheba). 11:3 there is an exaggeration in the messenger's response to David about Bathsheba's family. 11:4-5 - the adultery with Bathsheba is spoken of in understated language. 11:11- there is an exaggeration in the vow that Uriah makes on David's name. 12:5-6 - David's sentence placed on the rich man in the parable is exaggerated. 12:16-17-David's act of supplication after God's punishment is an exaggerated act. 12:27-28the repetition of the word ' $\mathrm{I}$ ' is exaggerated. 13:11-11a there is an overstatement in Tamar's language. 13:11 is curt. 13:16 - there is an overstatement of Tamar's language. 13:18 - the detail concerning Tamar's robe is overstated. 13:23-26a13:23-25 - Absalom uses overstated language, 13:26a is curt. 13:29 - the language detailing Amnon's murder is understated. 13:30-33-13:30a $a$-is verbose language (David is told that his sons have been killed), 13:32ab-is curt, also 13:32 b- 33 a is verbose, and 13:33 b is curt. 13:34- 36 - is overstated (report that it is only Amnon who was killed). 14:9-11-the woman of Tekoa uses overstated language. 14:20 - there is an overstatement in the woman of Tekoa's comment that David is all knowing. 14:22-Joab's actions are exaggerated. 14:25-26the description of Absalom is overstated. 14:28-30a-there is verbosity in the description of the incident of Absalom setting fire to his property, 14:3ob, the conciseness in the same episode is an indication of a distortion. 14:33-there is an understatement in David's reconciliation with Absalom. 14:33a prolix, and 14:33b curt. 15:7-the forty years that Absalom waited to ask David if he could go to Hebron is an exaggeration. 15:14-there is overstated language when David explains that his army must flee.15:21-Ittai's response to David is overstated. 16:5-16:5a prolix, and 16:5b curt. (Shimei is cursing David) 17:8-13Hushai's advice to Absalom is verbose. 18:13 - the soldier response to Joab's bribe is overstated. 19:4-8a-there is overstatement in Joab's speech. 19:24Mephibosheth's appearance is overstated.

4 Ibid., 13. 


\subsubsection{Ridicule}

Marcus claims that ridicule is making fun of a person by any means. This could take the form of making fun of a person's name, appearance, characteristics, or by concentrating on the embarrassing, and ignoble, situations which the protagonist finds himself/herself in. ${ }^{5}$

11:2-David is presented as a self-indulgent king who is more interested in taking a nap and looking at a beautiful woman than the war effort. 11:3 David is ridiculed in this verse since the messenger has to stress the high status and loyalty of Bathsheba's family members. 11:5-it might be ridiculing (of David) that Bathsheba falls pregnant to David through the act of adultery. 11:8 - it is ignoble for David to bribe Uriah and suggest that he defile himself. 11:2-3David's attempts to get Uriah drunk, so as to manipulate him into sleeping with Bathsheba, are ignoble. 11:14-15 — the act of David sending Uriah with his own death warrant is ignoble. 11:16-17- the death of Uriah and the other innocent soldiers is ignoble. 12:7-15a-God's punishment of David ridicules David.12:2728-David must be told to take the town or Joab will name it after himself. 13:6-7-David is tricked by Amnon. 13:23-26-David is tricked by Absalom. 13:32b-33a Jonadab needs to tell David that it is only Amnon who has been killed. 13:34-Absalom flees Jerusalem. 14:4-7-David is tricked by the woman of Tekoa. 15:1-Absalom's entrance into Jerusalem with chariots and running men ridicules David. 15:3-The innuendo is that David is not competent to carry out his job as the administrator of justice. 14:4-6-ridicules Absalom because he has to steal the hearts of the Israelites. David is also ridiculed by his son. 15:7-David is tricked by Absalom into letting Absalom go to Hebron. 15:8-Absalom is ridiculed since he believes that God has brought him back to Jerusalem. 15:10-Absalom's erroneous claim that he is king ridicules both him and David. 15:11-it ridicules David that two hundred men went with Absalom. 15:11 - it ridicules Absalom if he had to manipulate men to join his revolt, particularly given that Absalom believed that God blessed his actions. 15:14 - David flees Jerusalem. 15:16 — for David to leave the concubines behind to look after the house was foolish. 15:31-David's prayer for God to turn Ahithophel's counsel into foolishness appears to contradict David's acceptance of God's outcome. 16:5-David is cursed by Shimei who is a Saulide. 16:9-David allows himself to be cursed by Shimei. 16:10—David's suggestion that God has caused Shimei to curse David is foolish. 16:11-12 it is ridiculing that David allows Shimei to curse him. 16:18-19-Absalom is ridiculed by Hushai. 18:1-2a-David is ridiculed in his choice of leaders for his army. 18:9it is ignoble that Absalom is hung by his head in a tree as his mule rides off.

5 Ibid., 18. 
18:11-Joab is ignoble in attempting to bribe the soldier. I Kgs. 1:1-4-David's impotence is a means of ridicule. I Kgs. 1:11-35-David is ridiculed because either he cannot remember making an oath to one son or because he knowingly endorses two sons to be king at the same time.

\subsubsection{Parody}

For Marcus, parody is primarily the distortion of a known text, expression, or custom. However, parody can also be discerned in puns, paronomasia, and exaggeration, or when an entire narrative, genre, person, or characteristic is mocked. ${ }^{6}$

11:11-Uriah is either a foreigner or of foreign descent. Thereby, it is a parody that he informs the King of Israel of the rules for ritual purity with respect to the presence of the ark in battle. 11:19-21-David is mocked in Joab's monologue about Abimelech, and in Joab's assertion that the death of Uriah will take away suspected anger. 12:6-David is mocked in Nathan's Parable, particularly when he sentences the rich man to death. 12:18b — the sarcastic remark which identifies David with banned, self-mutilating, mourning rituals, is parody. 12:19-20-David is mocked when David appears to mourn before the child dies, but does not mourn after the child's death. 12:22-23-David's response to the servants after the child's death is a distortion of the custom of mourning. 13:8-9-Amnon abuses the custom of hospitality. 13:23-26-Absalom uses a sheep-shearing festival as a means of ambushing Amnon thereby distorting a custom. 14:11-a foreigner (the wise woman of Tekoa) tricks the King of Israel into swearing an oath. 14:13 - the woman of Tekoa tells David that he has convicted himself in giving his judgement since he has not returned Absalom to Jerusalem. 14:17 - the woman of Tekoa tells David that his word is like the angel of God who discerns good and evil. 15:12- "Ahithophel", the name, means "my name is folly." 15:12 - "Absalom", the name, means "my father is peace," yet in this passage he is waging war. 15:18-David's loyal men are mercenaries who sided with him, when he sought refuge with the Philistines. 15:24-29 - returning the arc of the covenant to Jerusalem to act as a cover for his spy network is a parody. 16:3-parodies the monarchy, as David, Absalom, and Mephibosheth all believe that they are the rightful King of Israel. 16:4David gives away Mephibosheth's estate without due process. 16:13-14-the story of David and Goliath is parodied in the story of Shimei pelting David and his army with stones. 16:20-23-Absalom's act of taking David's concubines means that he is now a rapist and has committed incest, just like Amnon. 16:20-23 - arguably the laws are being mocked throughout this narrative.

6 Ibid., 19-22. 
17:1-4-Absalom's acceptance of Ahithophel's advice might be parodying David's earlier situation in 11:1. 17:5-7-In order to counter Ahithophel's advice Hushai must give poor tactical advice, but good advice regarding the expectations of the Israelites. Absalom provides Hushai with Ahithophel's advice. 18:14-17-Absalom is defeated by the same advice he chose not to follow. I Kgs. 2:1-9 — the idea that kings are upright is parodied.

\subsubsection{Rhetorical Features}

Marcus writes that the rhetorical features which are particular to the Hebrew Bible include: paronomasia, repetitions of verbs, homophones, homographs, colloquialisms, obscene language, hapax legomena, and chiastic patterns. ${ }^{7}$

9:8 — the term 'dead dog' is an example of obscene language. 11:1; 11;3; 11:4; 11;5; 11:6 (x3) 13:7 13:16 — repetition of the verb send/sent. 11:11—-the word סכות is the name of a town and also refers to the festival of booths, making this a (possible) homophone. 13:4b - the use of alliteration. 15:31-there is a repetition of speaking verbs in this verse. 16:1—the use of the metaphor מהראש. 16:5一the use of an unsuitable metaphor, בחורים, which means chosen, however, David is fleeing from Absalom who believes he too is chosen. 17:8-13-paronomasia of verbal roots and oppositions, metaphor, simile and alliteration.

\subsection{Conclusion}

In conclusion, there are a very large number of instances of the non-essential features of satire present throughout the SN. Thus, the SN meets the requirement of the presence of non-essential features of satire. It has already been demonstrated that the SN meets the primary requirements for it to be satire, namely, the presence of a pervasive sense of verbal irony and, therefore, an object of ironic and satirical attack. Accordingly, I conclude that the SN is a work of satire.

7 Ibid., 23 . 